\title{
The use of productive technologies of professional education as a means of developing critical thinking and forming the subject of future teachers
}

\author{
N.A. Kalugina ${ }^{1 *}$, and T.V. Dmitrochenko ${ }^{2}$ \\ ${ }^{1}$ Federal State Educational Institution of Higher Professional Education "Pacific National University", \\ Khabarovsk, Russia \\ ${ }^{2}$ Amur State University of Humanities and Pedagogy, Komsomolsk-on-Amur, Russia
}

\begin{abstract}
The article describes the actual problem of the development of critical thinking and the formation of the subjectivity of the future teacher in modern conditions. A theoretical analysis of the literature on the problem considered is presented. On the basis of the analysis, in accordance with the purpose and subject of the research, the definitions of the concepts "subjectivity" and "critical thinking", specified by the author of this article, are given. The course and results of experimental work on the development of critical thinking and the formation of subjectivity of future teachers are described. The article provides the rationale for the developed diagnostic complex of methods necessary for the study. As a hypothesis, the authors put forward the statement that the subjectivity and critical thinking of future teachers do not develop without the use of a complex of productive technologies of professional education. The article provides a rationale for the complex of pedagogical technologies necessary for the development of critical thinking and the formation of the subjectivity of future teachers. The results of the study are presented, confirming the effectiveness of the used complex of pedagogical technologies and the dynamics of the formation of the studied personality traits of the future teacher.
\end{abstract}

\section{A problem statement}

In the context of the modernization of the modern world, an increase in the volume of knowledge and the amount of information, the digitalization of various spheres of modern society, the requirements for the personality and professional competence of a modern teacher are increasing. According to the regulatory documents of the Russian Federation (the Concept for the Development of Continuous Education of Adults in the Russian Federation for the Period up to 2025, the National Project "Education", the Federal State Educational Standard of Higher Education (FGOS VO $3++$ ), etc.), society today needs a

\footnotetext{
${ }^{*}$ Corresponding author: prof-ped.gpa@mail.ru
} 
teacher with developed skills of critical thinking, able to carry out personal and professional development not throughout his life.

The modern teacher is faced with the need to comprehend these requirements for his personality and professional training in the context of the modern educational paradigm. These requirements are quite high. Society needs not just a teacher who has formed groups of competencies listed in the standard of the direction of training, but also a professional who has sufficiently developed critical thinking skills that allow him to work efficiently with various types of professional information, use professional knowledge for personal and professional development in conditions continuing professional education.

The formation of critical thinking and the subjective qualities of the personality of a future teacher, which are a condition for the continuous growth of his educational potential, is noted in the Law of the Russian Federation "On Education", the Concept for the Development of Continuous Education of Adults in the Russian Federation for the Period up to 2025, the National Project "Education", the Federal State educational standard of higher education (FGOS VO $3++$ ) and other regulatory documents of the Russian Federation. The issues of the formation of the subjectivity of the teacher, the development of his critical thinking are also considered in the works of domestic researchers.

So, for example, the scientist-psychologist A.S. Bayramov considers critical thinking as the ability of a person not to take statements completely on faith, to check the truth of statements, the ability to develop his own critical view and critical attitude to events and phenomena of reality [1, p. 34]. The famous teacher M.V. Clarin has a similar point of view. In his works, critical thinking is associated with the characteristics of rationality, purposefulness, organization, reflexivity [1].

Researcher Yu.A. Kukushkina defines critical thinking as an interconnected complex of cognitive and matacognitive strategies and skills for solving life and professional problems. The scientist examines the phenomenon of critical thinking in the context of the professional training of a future specialist and notes that this skill is a condition for the success of solving professional problems [2].

The phenomenon we are studying is considered as a reflexive process of "awareness of one's thinking" in the works of T.A. Olkhova. The researcher does not reduce critical thinking only to a set of intellectual abilities and skills, but considers it as the basis for the development of information and cognitive activity of the individual, while recognizing the importance of the individual's readiness to use these non-objective skills not only in educational activities, but in real life situations [3].

E.S. Zair-Bek considers critical thinking as a personality trait interconnected with the semantic self-determination of the personality [4]. I.A. Morochenkov and N.Yu. Tulasynova associate critical thinking with the processes of self-knowledge, self-education and self-realization [5]. The relationship between critical thinking and subjectivity was noted in the works of T.A. Olkhova and T.S. Khabarova [3].

Within the framework of this study, critical thinking is understood as the reflexive thinking of a future teacher, which allows him to effectively work with various types of professional information (compare, analyze, evaluate), distinguish facts from assumptions, provide arguments in defense of his opinion, solve typical and non-standard professional problems.

Critical thinking can be considered as a means of forming the subjectivity of a student of a pedagogical university, which allows him not only to work effectively with information, but also to comprehend his own personal and professional advantages and disadvantages, to build a vector of his development, to self-develop and self-actualize in the conditions of continuous professional education.

The phenomenon of personality subjectivity is considered in the works of scientists K.A. Abulkhanova-Slavskaya, B.G. Ananyeva, L.I. Antsiferova, T.V. Belykh, A.V. 
Brushlinsky, E.Yu. Korzhova, D.A. Lont'ev, B.F. Lomov, S.L. Rubinstein, V.E. Chudnovsky, M.A. Shchukina. By subjectivity, these scientists understand one of the key characteristics of a person, which allows her to be an active subject and creator of her own life, to consciously and responsibly treat her activities, to carry out reflection and selfdevelopment throughout her life [6].

The issues of the student's professional subjectivity are considered in the works of N.M. Borytko, A.A. Derkach, F.G. Mukhametzyanova V.A. Slastenin. In the works of these researchers, the professional subjectivity of a future specialist is represented by a multifaceted characteristic of his personality, marked by an active creative attitude to the profession he receives, successful adaptation in a constantly changing socio-cultural situation, the manifestation of independence and activity in the professional and educational space of the university, the implementation of productive pedagogical interaction with the subjects of the educational process; with an awareness of responsibility for the results of the education they receive [7].

Within the framework of this study, the professional subjectivity of a future teacher is understood as the integrative quality of his personality, which is determined by a sufficient level of reflection, self-knowledge, subjective experience, allowing the student, as a future subject of pedagogical activity, to carry out continuous self-development and selfrealization in the conditions of continuous professional education.

\subsection{The objective of the work}

The purpose of the work is to substantiate a complex of productive technologies of vocational education, contributing to the formation of subjectivity and the development of critical thinking of future teachers.

\section{Results of the research}

Experimental work on the development of critical thinking and the formation of the subjectivity of future teachers included the ascertaining, forming, control stages.

At the ascertaining stage of the pedagogical experiment, we studied the levels of subjectivity and the development of critical thinking among the students of the control and experimental groups.

The object of our research was the professional educational process of a pedagogical university. The subject of the research is the level of subjectivity and the development of critical thinking of future teachers studying at the Amur State Humanitarian Pedagogical University.

The hypothesis of this study was the assumption that the formation of subjectivity and the development of critical thinking of future teachers will be facilitated by the use of a complex of productive technologies of vocational education in the vocational and educational process of a pedagogical university. The aim of the study was to test and test the effectiveness of the complex of these pedagogical technologies.

In our work, we applied a set of the following methods of pedagogical research: theoretical (analysis, synthesis and generalization of scientific literature), empirical (testing, rating, method of expert assessments), methods of mathematical statistics (Spearman's correlation coefficient, multifunctional Fisher's criterion).

The experimental research group (hereinafter referred to as the EG) consisted of 20 people, students of the 2nd year of the training direction 44.03.05 "Pedagogical education (with two training profiles)", profiles "Russian language" and "Literature". The control group of the study (hereinafter referred to as the CG) consisted of 22 people, the second- 
year student of the specialization 44.03.05 "Pedagogical education (with two training profiles)", profiles "Primary education" and "Foreign language".

The presented sample consisted of students with an average and high level of academic performance, stable motives for educational and professional activities, who want to connect their future professional activities with work in educational organizations. It should be noted that with the presented groups of students at the early stages of training, purposeful formative work was not carried out to develop the qualities we are studying.

To identify the level of subjectivity and the development of critical thinking of students, we have developed a set of diagnostic techniques. We determined the level of personality subjectivity based on their sum of indicators: self-knowledge ("Methodology for the study of self-attitude" (S.R. Pantileev) [8], actualized subjective experience and reflection ("Questionnaire of reflexivity" (A.V. Karpov) [9], self-realization ("Multidimensional questionnaire of personality self-realization" (S.I. Kudinov) [10]. For each individual methodology, we identified the level of personality subjectivity indicators (sufficient, average, low). summing up the indicators, we determined the level of the general level of subjectivity of each student as an integral quality of his personality.

To determine the level of development of critical thinking of students-teachers, we have developed a methodology aimed at assessing the skills of critical work of students with educational and professional information. This methodology was taken from the International Program for the Assessment of Educational Achievements of Students (PISA), refined and tested in relation to the process of professional training of a future teacher. The tasks presented in the text will allow to evaluate the skills of information analysis, synthesis, deduction, induction, the ability to check the truth of various statements, to distinguish between facts and assumptions, to establish cause-and-effect relationships between phenomena, to solve non-standard life and professional-pedagogical tasks in a situation of uncertainty.

At the ascertaining stage of the pedagogical experiment in the EG, a sufficient level of subjectivity was revealed in $25 \%$ of the research participants, the average level - in $50 \%$ of the tested, low - in $25 \%$ of the students. A sufficient level of critical thinking development was revealed in $20 \%$ of the tested from the EG, in $55 \%$ of students - an average level, in $25 \%$ - a low level.

In the CG, a sufficient level of subjectivity was found in $18 \%$ of the study participants, the average level - in 55\% of the subjects, low - in $27 \%$ of the students. A sufficient level of development of critical thinking was revealed in $14 \%$ of the subjects of the CG, in $64 \%$ of students - an average level, in $22 \%$ - a low level.

The assessment of the reliability of differences between the percentages of the two samples from the EG and the CG was carried out using the multifunctional Fisher's test $(\varphi *$ -criterion). Since the obtained $\varphi *$ emp. $=0.553$ is less than $\varphi *$ critical $=1.64$, this means that at the level of significance $p>0.05$, the percentage of future teachers from the EG and $\mathrm{CG}$ with sufficient and average levels of development of critical thinking and subjectivity is significant do not differ.

Since, according to the results of the ascertaining stage of the research, an insufficient level of formation of the studied qualities of future teachers was determined. We proposed a complex of productive technologies for vocational education, contributing to the development of critical thinking and the formation of the subjectivity of future teachers.

We refer to pedagogical technologies for the development of critical thinking and the formation of the subjectivity of future teachers as subject-activity and communicativepersonal pedagogical technologies of vocational education, which are a combination of educational, organizational and educational approaches, principles, methods, techniques and forms of becoming a future specialist in conditions of continuous professional education. ... These technologies are aimed at activating the student's internal potential, 
developing his information and cognitive activity, gaining experience in creative activity, awareness of his own professional competence, the ability to critically evaluate information, and carry out the process of his own professional development.

These technologies include the following: technology for the development of critical thinking, dialogue, game technologies, technologies of problem learning, semantic reading, research, heuristic, project technologies, technology of contextual learning.

The implementation of the technology for the development of critical thinking in the educational process of the university allows students to holistically comprehend the subject under study, establish intra-subject connections with already known information, and form their own attitude to the material being studied. The use of a three-stage algorithm of this technology, various technological techniques and methods is aimed at organizing perception, critical comprehension, interpretation, and comprehensive analysis of scientific information obtained from written sources. We include the following as methodological techniques for the development of critical thinking: cluster, syncwine, logbook, ZXU table, Bloom's chamomile, text marking, reading with stops, brainstorming, a basket of ideas, etc.

Dialogue pedagogical technologies are aimed at developing dialogue, critical thinking, communicative culture of the future teacher, his activity and independence in educational and professional activities. These technologies allow the student to independently express their own thoughts and judgments, express their attitude to the material being studied, teach the ability to understand and accept the position of other participants in the dialogue. These include technologies of educational dialogue, problem-search dialogue, educational discussion, debates, heuristic conversations, analysis of specific situations.

Game pedagogical technologies are aimed at enhancing and intensifying students' activities through modeling the context of future professional activities in the form of various pedagogical games. These technologies are aimed at updating the life experience of students, disclosing personal potential, acquiring new knowledge and ways of future pedagogical activity. Game technologies activate creative, critical thinking of students, allow to bring the process of theoretical learning closer to practice. In the practice of a pedagogical university, didactic games, problem-business, situational-role, organizationalactivity, reflexive-business games, game design, imitation exercises, playing out pedagogical situations in roles are most often used.

The technology of problem-based learning in vocational education is aimed at enhancing the independent cognitive activity of students, which consists in finding and resolving complex issues of future pedagogical activity. The presented technology is aimed at creative mastering of professional knowledge, skills and abilities, as a result of which the mental abilities of the future teacher, his critical, systemic, analytical thinking, the ability to draw conclusions and determine laws and patterns, independently solve professional problems of varying degrees of complexity, develop. The implementation of this technology is carried out through the use of problem lectures and seminars, lectures with pre-planned errors, the method of problem presentation, and a partial search method in the vocational and educational process of a pedagogical university.

The technology of semantic reading in vocational education contributes to the formation of reading literacy, the skills of productive work with different types of texts, to achieve an understanding of the informational, semantic, ideological aspects of various educational and scientific texts. This technology allows you to form the ability to analyze and interpret texts, isolate the main and secondary information, critically evaluate it, form your own attitude to what you read.

Research, heuristic, design technologies in vocational education are aimed at enhancing the independent information and cognitive, search activity of students, updating the existing subject experience, acquiring and understanding new professional experience, creating a finished product of one's own educational and professional activities. These include the 
writing of scientific articles by students, conducting mini-research, the development of abstracts of lessons and educational activities, the writing and defense of research, creative, social projects, etc.

One of the rather flexible technologies of vocational education, which includes a whole range of various pedagogical technologies, methods and techniques that ensure the development of critical thinking and the formation of the subjectivity of future teachers, is the technology of contextual learning. The technology under consideration involves the use of a procedure for modeling the context of future professional activity, immersing students in the particular profession of the profession, acquiring professionally important qualities, knowledge, abilities, skills and competencies through solving professional problems in a pre-designed context of future professional and pedagogical activity. This technology is universal in the professional educational process of a pedagogical university, since it meets a number of main didactic principles - the connection between theory and practice, activity, consciousness, and is also aimed at the formation of flexible, critical thinking and the formation of the subjective qualities of the future teacher in the process of solving professional problems.

The use of all of these technologies in the vocational and educational process of a pedagogical university contributes to the formation of a holistic image of a future competitive specialist with developed critical thinking, a sufficient level of subjectivity, capable of carrying out professional development throughout his life.

At the stage of the control experiment, based on the results of the conducted formative work, we can find the dynamics of changes in the level of development of critical thinking and the formation of the subjectivity of future teachers, presented in Table 1.

Table 1. Dynamics of changes in the level of development of critical thinking and the formation of subjectivity of future teachers.

\begin{tabular}{|c|c|c|c|c|c|c|c|}
\hline \multirow[t]{2}{*}{ Quality } & \multirow[t]{2}{*}{ Stage } & \multicolumn{2}{|c|}{ Enough level } & \multicolumn{2}{|c|}{ Average level } & \multicolumn{2}{|c|}{ Low level } \\
\hline & & $\begin{array}{c}\text { number } \\
\text { of } \\
\text { persons }\end{array}$ & $\%$ & $\begin{array}{c}\text { number } \\
\text { of } \\
\text { persons }\end{array}$ & $\%$ & $\begin{array}{c}\text { number } \\
\text { of } \\
\text { persons }\end{array}$ & $\%$ \\
\hline \multicolumn{8}{|c|}{ Experimental group (EG) } \\
\hline \multirow[t]{2}{*}{ Subjectivity } & $\begin{array}{l}\text { Experiment } \\
\text { start }\end{array}$ & 5 & 25 & 10 & 50 & 5 & 25 \\
\hline & $\begin{array}{l}\text { End of } \\
\text { experiment }\end{array}$ & 7 & 35 & 12 & 60 & 1 & 5 \\
\hline \multirow[t]{2}{*}{$\begin{array}{l}\text { Developing } \\
\text { critical thinking }\end{array}$} & $\begin{array}{l}\text { Experiment } \\
\text { start }\end{array}$ & 4 & 20 & 11 & 55 & 5 & 25 \\
\hline & $\begin{array}{l}\text { End of } \\
\text { experiment }\end{array}$ & 6 & 30 & 13 & 65 & 1 & 5 \\
\hline \multicolumn{8}{|c|}{ Control group (CG) } \\
\hline \multirow[t]{2}{*}{ Subjectivity } & $\begin{array}{l}\text { Experiment } \\
\text { start }\end{array}$ & 4 & 18 & 12 & 55 & 6 & 27 \\
\hline & $\begin{array}{l}\text { End of } \\
\text { experiment }\end{array}$ & 4 & 18 & 14 & 64 & 4 & 18 \\
\hline \multirow[t]{2}{*}{$\begin{array}{l}\text { Developing } \\
\text { critical thinking }\end{array}$} & $\begin{array}{l}\text { Experiment } \\
\text { start }\end{array}$ & 3 & 14 & 14 & 64 & 5 & 22 \\
\hline & $\begin{array}{l}\text { End of } \\
\text { experiment }\end{array}$ & 3 & 14 & 16 & 73 & 3 & 13 \\
\hline
\end{tabular}

Analysis of the data presented in table 1 allows us to make a conclusion about a more pronounced positive dynamics in the development of critical thinking and the formation of subjectivity of students from the EG. As a result of the analysis of the obtained data, it can be argued that in the EG there was a significant decrease in the proportion of future 
teachers with a low level of the studied qualities, and an increase in the proportion of students with sufficient and average levels of development of critical thinking and subjectivity.

To identify changes in the dynamics of the development of critical thinking and the formation of the subjectivity of future teachers, the methods of expert assessments (university teachers and employers) and self-assessment were additionally used. To assess the reliability of differences between the percentages of the two samples from the EG and the $\mathrm{CG}$ at the end of the OER, the multifunctional Fisher test $(\varphi *$-test) was applied. Since the obtained $\varphi^{*}$ emp. $=1.885$ is more than $\varphi^{*}$ critical $=1.64$, then $\varphi^{*}$ emp. fell into the zone of "significance of differences", which gives grounds to assert that there are significant differences in the percentage shares with sufficient and average levels of the studied qualities of students from the EG and CG at the end of the OER in comparison with its beginning.

\section{Conclusions}

Thus, the experimental work carried out on the development of critical thinking and subjectivity of future students was effective, made it possible to achieve the objectives of the study, to confirm its hypothesis and the effectiveness of the implementation of a complex of productive technologies of vocational education. According to the results of the work carried out, it can be noted that the number of students with a sufficient and average level of development of critical thinking and the formation of subjectivity has increased. This is reflected in the personal and professional growth of students, improving their academic performance, the formation of sustainable professional interest and desire to develop throughout their lives.

\section{References}

1. L.V. Astahova, The cognitive environment of modern scientific libraries: The concept and structure, Scientific and technical libraries, 7, 3-15 (2018)

2. D.V. Berdnikova, Research of personality activity in Russian and foreign psychology, Psychology. Historical and critical reviews and modern research, 2, 8-20 (2016)

3. N.M. Borytko, Education as a humanitarian educational practice, Innovative educational technologies: Quarterly scientific, production and practical journal, 2, 43$50(2005)$

4. S.I. Zair-Bek, Developing critical thinking in the classroom: a guide for teachers of educational institutions, Bulletin of the Lobachevsky University of Nizhny Novgorod, 6, 11-21 (2007)

5. T.A. Karlina, Subjectivity as an important condition for the formation of personality, Young scientist, 52(290), 265-267 (2019)

6. A.V. Karpov, Reflexivity as a mental property and a technique for its diagnosis, European Proceedings of Socialand Behavioural Sciences, 24(5), 45-57 (2003)

7. S.I. Kudinov, System model of personal self-realization, Bulletin of the RUDN. Ser. "Psychology and pedagogy", 1, 28-37 (2008)

8. I.A. Morochenkova, Formation of students' critical thinking in the educational process of the university, Dissertation abstract for the degree of candidate of Pedagogy, 6, 22 (2004) 
9. T.A. Ol'hovaja, Critical thinking as the basis for the development of information and cognitive independence of students, 9, 46-51 (2013)

10. S.R. Pantileev, Self- attitude research methodology, Psychodiagnostic series, 7, 32 (1993)

11. G.A. Pozdnjakova, Critical thinking as an integrative personality trait, Bulletin of the Samara State Technical University. Series: Psychological and pedagogical sciences, 4(24), 208-213 (2014)

12. I.A. Seregina, The psychological structure of subjectivity as a personal property of a teacher, 24 (1999)

13. T.S. Habarova, Critical thinking development technology as a means of forming the subjectivity of medical students, 149 (2016)

14. V. Kiryakova, The Axiological Approach to the Analysis of the Problems of Modern University Education, Mediterranean Journal of Social Sciences, 6(2), 22-28 (2015)

15. A. Olkhovaya, A Synergy-Based Approach through Developing Cross-Disciplinary Module, International Electronic Journal of Mathematics Education, 11, 467-474 (2016) 